\title{
DYNAMIC REPETITION KARAKTER RANGGA DALAM STICKER LINE "Alumni AADC Special stickers".
}

\author{
${ }^{1}$ Riky Azharyandi Siswanto, ${ }^{2}$ Mohamad Tohir \\ 1,2Program Studi Desain Komunikasi Visual, Univeristas Telkom \\ 1 riky@tcis.telkomuniversity.ac.id \\ 2 mtohir@tcis.telkomuniversity.ac.id
}

\begin{abstract}
ABSTRAK
Aplikasi ponsel pintar LINE sebagai salah satu communication app (messenger) yang banyak diminati oleh pelbagai khalayak menawarkan emoji dalam bentuk yang lebih populer-biasa disebut dengan sticker. Sama seperti emoji, kelahiran sticker merupakan hasil percepatan ICT dalam "meringkas" komunikasi yang mengungkapkan perasaan (baca: emosi). Sticker LINE juga memiliki fungsi utama yaitu "peringkas komunikasi" dalam menggambarkan perasaan seseorang kepada orang lain dalam bentuk yang sederhana tetapi dapat dimaknai ke dalam beberapa level komunikasi. Karakter Rangga dalam rancangan sticker LINE "Alumni AADC Special stickers" diciptakaan sebagai media pendukung dari iklan LINE - Ada Apa Dengan Cinta Mini Drama (AADC 2014) yang terdapat di YouTube. Iklan tersebut memanfaatkan popularitas film Ada Apa Dengan Cinta (AADC 2002), maka image Rangga di benak pengguna layanan LINE adalah karakter Rangga yang terakumulasi dari film AADC 2002 \& iklan LINE AADC 2014 (Mini Drama), dalam merancang Sticker LINE pengembangan karakter dipengaruhi oleh memori Visual yang berisi karakteristik/pengalaman dari kemampuan yang bersumber dari pengalaman visual, Akan tetapi sebagai rancangan sticker LINE Rangga dalam "Alumni AADC Special stickers" dirasa tidak merepresentasikan karakteristik yang tercitrakan dari film AADC 2002 dan iklan LINE AADC 2014, seharusnya image tokoh yang seharusnya dipertahankan sebagai satu identitas yang lekat di benak audience.
\end{abstract}

Kata Kunci : ICT, LINE Sticker, Semiotic Communication.

\begin{abstract}
LINE, a smartphone application, as one of communication apps (messenger) appreciated by public offers emoji in a more popular form - commonly called as sticker. Similar to emoji, the emergence of sticker is a form of advancement in ICT as to "shorten" the communication that expresses feelings (read: emotion). LINE sticker has also a main function, i.e. "to shorten communication" in describing one's feeling to others in a simple form but it can be defined into several levels of communication. The character of Rangga in the design of LINE sticker - "Alumni AADC Special stickers" - was created as a supporting medium of LINE commercial - Ada Apa Dengan Cinta Mini Drama (AADC 2014) in YouTube. The commercial uses the popularity of Ada Apa Dengan Cinta (AADC 2002) movie that makes LINE users create an image of the character of Rangga as accumulated from the AADC 2002 movie \& LINE AADC 2014 (Mini Drama) commercial. In designing LINE sticker, the character development is influenced by visual memory consisting of characteristic/experience of abilities derived from visual experience. However, likely, as a LINE sticker design, Rangga in "Alumni AADC Special stickers" does not represent the characteristic depicted in the AADC 2002 movie and LINE AADC 2014 ads which in fact, the image should be maintained as an identity remembered by audience.
\end{abstract}

Keywords : ICT, LINE Sticker, Semiotic Communication. 


\section{PENDAHULUAN}

Percepatan ICT (information and communications technology) di dalam ponsel pintar khususnya secara signifikan telah melahirkan komunikasi artifisial yang memiliki sentuhan emosional sebagai pengganti komunikasi langsung yang dekat dengan penggunanya, contohnya adalah emoticon dan emoji, kelahirannya merupakan hasil percepatan ICT dalam "meringkas" komunikasi dalam mengungkapkan perasaan (baca: emosi). LINE sebagai salah satu communication app (messenger) yang banyak diminati oleh pelbagai khalayak menawarkan emoji dalam bentuk yang lebih populer, biasa disebut dengan sticker. Sama seperti emoji, sticker LINE memiliki fungsi "peringkas komunikasi” dalam menggambarkan perasaan seseorang kepada orang lain dalam bentuk yang sederhana tetapi dapat dimaknai kedalam beberapa level komunikasi.

Sebagai sebuah bentuk komunikasi, sticker LINE merupakan "pesan" yang disampaikan oleh si pengguna. Berbeda dengan sticker pada messenger lainnya, sticker LINE memiliki karakteristik yang lebih kuat, seperti gayanya yang lebih ilustratif dan nilai estetisnya yang lebih terlihat sebagai upaya "meringkas" pesan emosional yang ingin disampaikan di dalam bentuk komunikasi diatas. Oleh sebab itulah, sticker LINE berkembang tidak hanya sebagai "peringkas" emosi saja melainkan merepresentasikan budaya popular dan menjadi populis karenanya, bahkan beberapa karakter sticker LINE telah menjadi "property intelektual” yang berhasil dikomersilkan. Secara praktis, sticker LINE dapat menghemat waktu dalam berkomunikasi via line, akan tetapi dapat pula menyebabkan makna komunikasi yang tidak lengkap bahkan dapat menimbulkan kesalahpahamaan dalam memaknainya.

Indonesia tercatat sebagai pengguna LINE terbesar kedua di dunia setelah Jepang, dengan 30 juta pengguna berdasarkan data yang diperoleh dari Asahi. Pada akhir tahun 2014, LINE mengeluarkan fitur baru yaitu Find Alumni. Galuh Chandrakirana, Team Leader Marketing LINE Indonesia, mengatakan: "Kami menyadari kebutuhan untuk berkomunikasi selalu ada. Tak hanya pada orang di sekeliling kita hari ini, tetapi juga terhadap orang-orang yang pernah dekat dengan kita di waktu lampau. Itulah alasan LINE menciptakan fitur Find Alumni".

Dalam rangka mempromosikan fitur baru tersebut, LINE Indonesia membuat sebuah iklan yang dipublikasikan melalui YouTube, yaitu sebuah iklan dengan format film pendek dengan iklan yang diusung oleh media sosial LINE sangatlah unik dan sangat menarik perhatian khalayak umum, karena iklan yang disajikan tidak hanya berisikan tentang promo produk terbaru LINE (hard selling) tetapi juga mengaitkan dengan film AADC yang pernah booming di tahun 2002, dengan melihat iklan berdurasi 10 menit 24 detik tersebut di YouTube, penonton yang merupakan konsumen dan calon konsumen dapat melihat bagaimana maksud dari periklanan tersebut.

Film AADC yang ditampilkan oleh LINE ditampilkan sebagai kelanjutan dari film drama AADC yang pernah fenomenal di Indonesia pada tahun 2002. Iklan LINE versi AADC 2014 ditampilkan di YouTube, membuat para audience dapat menikmati iklan film tersebut pada layanan Youtube dan tidak merasakan sedang menonton iklan. 
Selain film pendek, LINE juga membuat set Sticker bertemakan karakter- karakter yang ada di film AADC berjudul "Alumni AADC Specialcial stickers". Sticker set yang pertama berisikan 24 Sticker yang terdiri dari 6 Sticker tokoh Cinta, 6 Sticker tokoh Rangga, Tokoh Milli dan Karmen, masingmasing berjumlah empat Stickers, Alya dan Maura berjumlah masing-masing dua Stickers. Objek yang dijadikan bahan penelitian terdiri dari enam stickers dari tokoh Rangga saja. Tujuan dari penelitian ini adalah untuk mengetahui unsur-unsur yang tergambarkan dari tokoh Rangga dari film AADC kedalam konten Sticker LINEset "Alumni AADC Special stickers". Akan tetapi rancangan sticker LINE Rangga dalam "Alumni AADC Special stickers". Dirasa tidak me-representasikan karakteristik yang tercitrakan dari Film AADC 2002 dan iklan LINE AADC 2014. Hal ini tidak sejalan dengan teori Meme (repetisi) dimana manifestasi karakter Rangga dalam sticker LINE haruslah mengacu pada memori audience tentang ikon yang dijadikan konten perancangan.

\section{PERMASALAHAN}

Adakah hubungan Dynamic Repetition antara karakter Rangga dalam Film AADC 2002, Iklan LINE AADC 2014 dengan sticker LINE "Alumni AADC Special stickers"?

\section{METODOLOGI}

Penelitian ini adalah penelitian kualitatif dimana untuk memahami unsur yang dijadikan konsep untuk konten rancangan karakter Rangga dalam Sticker LINE "Alumni AADC Special stickers", maka dirasa perlu untuk mengobservasi Film AADC 2002 dan film pendek AADC 2014 sebagai bahan acuan dan pijakan yang valid dalam konteks untuk mengetahui karakteristik dan perwatakan dari tokoh Rangga. AADC 2002 dijadikan sumber yang mempengaruhi perwatakan dari Iklan LINE AADC 2014, dimana karakter digambarkan mengalami perubahan dan perkembangan dari berbagai aspek, baik fisik dan perilaku kesehariannya, selanjuatnya citra dari kedua karakter yang terproyeksikan dalam kedua film tersebut akan dijadikan pembanding dengan citra yang diilutrasikan pada tokoh Rangga dalam Sticker LINE "Alumni AADC Special stickers".

\section{TINJAUAN TEORI}

Sticker (LINE) lahir di Jepang pada tahun 2011 pada saat sebuah perusahaan internet asal Korea bernama NAVER tengah mengembangkan aplikasi LINE di Jepang. Sticker LINE merupakan pengembangan dari Emoticon dan Emoji. Pada awal tahun 2012, LINE sebagai sebuah aplikasi pengirim pesan atau messenger mengembangkan sticker LINE sehingga menjadi tokoh-tokoh pop-culture sepeti Brown and Cony, Moon. Karakter-karakter tersebut menjadi semakin populer akibat LINE memanfaatkan ikon-ikon tersebut sebagai "properti intelektual" dimana karakter-karakter tersebut di aplikasikan sebagian ke dalam cenderamatacederamata berupa boneka dan produkproduk lainnya yang memiliki nilai ekonomis. Sama seperti Emoticon, Sticker LINE berfungsi sebagai alat untuk mengekspresikan humor, menyimbolkan perasaan. Riset pasar menunjukkan bahwa para penguna LINE lebih merasa mudah untuk meminta maaf menggunakan sticker LINE dibandingkan dengan teks, ini membuktikan bahwa Sticker LINE mampu mengekspesikan pelbagai emosi yang tidak mampu diungkapkan melalui tulisan. 
Sticker LINE merupakan simbol yang di gunakan untuk berkounikasi secara verbal, maka prinsip-prinsip gestalt tidak dapat dilepaskan sebagai salah satu tolok ukur efektifitas dan kualitas simbol pada Sticker LINE, dan prinsip-prinsip tersebut adalah:

- Prinsip kedekatan : objek visual yang terletak berdekatan atau tampil di dalam waktu yang bersamaan cenderung dipersepsi sebagai satu kesatuan.

- Prinsip kemiripan : objek visual yang memiliki struktur yang sama atau mirip cenderung dipersepsi atau dilihat sebagai satu kesatuan.

- Prinsip searah : objek visual cenderung dipersepsi sebagai satu kesatuan apabila berada di dalam satu arah pandangan.

Dalam Konteks menganalisa karakter Rangga dalam Sticker LINE "Alumni AADC Special stickers" diperlukan tinjauan terhadap salah satu unsur yang penting dalam membentuk icon yang ideal (menurut teori Gestalt) dimana pengalaman visual memiliki peran yang penting dalam kesuksesan perancangan karakter Rangga dalam "Alumni AADC Special stickers".

Pengalaman visual sendiri adalah proses mengingat (retrieval) dimana proses mengingat kembali dari apa yang telah disimpan pada tahap kedua. Mengingat kembali merupakan suatu proses mencari dan menemukan informasi yang disimpan dalam memori untuk suatu keperluan atau kebutuhan. Proses mengingat diketahui dengan empat cara sebagai berikut:

- Recall, adalah proses aktif untuk menghasilkan kembali informasi dan fakta secara kata demi kata Verbatim) tanpa adanya petunjuk yang jelas.Contohnya mengingat merek sebuah sepatu dengan tanpa adanya sepatu yang sedang diingatnya tersebut

- Recognition, adalah proses mengenal fakta agak lebih mudah dari pada mengingatnya kembali. Contohnya mengingat merek sepatu ketika melihat bendanya atau bentuk sepatunya.

- Reintegrative, adalah proses melakukan rekonstruksi seluruh masa lalu (past) dari satu petunjuk (sign) memori kecil. Petunjuk memori ini bisa berupa bau-bauan, warna, atau suatu tempat. Contoh dari proses mengingat jenis ini adalah ketika seseorang sedang berada di suatu restoran dan tempat itu mengingatkan ia tentang memori akan sesuatu kejadian seperti makan dengan seseorang yang spesial.

- Relearning, adalah proses menguasai kembali pelajaran (pengetahuan) yang sudah kita peroleh termasuk pekerjaan memori.

Manusia dapat meletakkan informasi berupa memori visual yang menyerupai objek, seperti: tempat, hewan, ataupun manusia dalam bentuk gambar. Memori visual adalah bagian dari suatu sistem kognitif yang saling berkaitan dan berkumpul satu dengan yang lain, sehingga membentuk suatu bentuk memori manusia yang utuh. Proses selanjutnya setelah seseorang mengakses memorinya maka akan timbul persepsi. Persepsi merupakan suatu proses menginterpretasi atau menafsirkan informasi yang diperoleh melalui sistem alat indera manusia. Misalnya, pada waktu seseorang melihat sebuah lukisan, membaca tulisan, atau mendengarkan musik, ia akan melakukan interpretasi berdasarkan pengetahuan yang relevan dengan hal-hal itu. Berdasarkan pemahaman tersebut, maka persepsi mencakup dua proses yang berlangsung secara serempak antara keterlibatan aspek- 
aspek dunia luar dengan dunia didalam diri seseorang. Dua proses didalam memori itu disebut bottom-up atau data-driven processing (aspek-aspek stimulus), dan top down atau conceptually processing (aspek pengetahuan seseorang).

\subsection{Pertandaan}

Elemen dasar pada semiotika adalah tanda, menurut Saussure tanda merupakan objek fisik dengan sebuah makna; atau sebuah tanda (sign) terdiri atas penanda (signifier) dan petanda (signified). Penanda adalah citra fisik tanda seperti yang kita persepsi (seperti tulisan diatas kertas atau suara diudara); petanda adalah konsep mental yang diacukan penanda. Aturan main yang menjadi syarat adalah konsep mental yang sama pada semua anggota kebudayaan yang sama, juga dalam penggunaan bahasa yang sama.

Penanda + Petanda $=$ Tanda

Gambar 1. Struktur tanda menurut Saussure Sumber: Piliang. 2010: 258

\subsection{Tingkatan Tanda}

Pemaknaan dari sebuah teks hanya dimungkinkan bila tanda-tanda dikombinasikan dalam aturan tertentu, karena hubungan penanda dan petanda bukanlah terbentuk secara alamiah, melainkan terbentuk berdasarkan kesepakatan/konvensi, maka sebuah penanda membuka berbagai peluang bagi petanda atau makna.

Roland Barthes mengembangkan dua tingkatan pertandaan (staggered systems), yang memungkinkan untuk dihasilkannya makna yang juga bertingkat-tingkat, yaitu tingkat denotasi (denotation) dan konotasi (connotation). Denotasi adalah tingkat pertandaan yang menjelaskan hubungan antara penanda dan petanda, atau antara tanda dan rujukannya pada realitas, yang menghasilkan makna yang eksplisit, langsung, dan pasti. Makna denotasi (denotative meaning), dalam hal ini, adalah makna pada apa yang tampak.

Konotasi adalah tingkat pertandaan yang menjelaskan hubungan antara penanda dan petanda, yang didalamnya beroperasi makna yang tidak eksplisit, tidak langsung, dan tidak pasti (artinya terbuka terhadap berbagai kemungkinan). Ia menciptakan makna-makna lapis kedua, yang terbentuk ketika penanda dikaitkan dengan berbagai aspek psikologis, seperti perasaan, emosi, atau keyakinan. Selain itu, Roland Barthes juga melihat makna yang lebih dalam tingkatannya, akan tetapi lebih bersifat konvensional, yaitu makna-makna yang berkaitan dengan mitos. Mitos dalam pemahaman semiotika Barthes adalah pengkodean makna dan nilai-nilai sosial (yang sebetulnya arbitrer atau konotatif) sebagai sesuatu yang dianggap alamiah. Tingkatan tanda dan makna dari Barthes ini dapat digambarkan sebagai berikut:

Tanda $\Rightarrow$ Denotasi $\Rightarrow$ Konotasi (kode) $\Rightarrow$ Mitos

Gambar 2. Tingkatan tanda dan Makna Sumber: Piliang. 2010: 262

Tanda tidak saja dibicarakan dalam hal relasi, kode dan maknanya, tetapi juga dalam hal produksi sebagai proses penciptaan. Tanda bisa diproduksi atau direproduksi, Mihaly Csikzentmihaly menggunakan istilah Meme untuk menjelaskan unit informasi kultural, yang merupakan padanan kata dari istilah gen (gene), untuk menjelaskan pesan-pesan yang dikodekan secara kimia didalam 
organisme hidup. Istilah meme itu sendiri berkaitan dengan kata mimesis (Yunani), yang berarti meniru. Berikut beberapa definisi meme yang dikutip dari Piliang (2010):

- Meme has it root in Greek mimesis, means 'to imitate'.

- $\quad$ Meme is a 'cultural information' which is reproduced and replicated with a model similar to gene replication (Mihaly Csikzentmihaly).

- Meme is a cultural instruction that continuing from one generation to another through imitation and examples.

- $\quad$ Cultural massages are inherited from one generation to another through a cultural mimesis.

Secara tidak disadari meme diwariskan sebagai pesan-pesan kultural yang terus berlangsung dalam kehidupan masyarakat. Sesuatu ditiru karena dicontohkan, sesuatu dibuat kembali tanpa merubah karena memang harus begitu, meme terus diwariskan turun temurun, dari satu generasi ke generasi berikutnya seperti kode genetik yang terdapat pada setiap makhluk hidup yang diwariskan dari orang tua kepada anaknya dan tidak bisa ditolak. Meme, secara alamiah mempengaruhi bentuk kesadaran manusia yang menjadi pewarisnya, ia mampu membangun dan mengendalikan pikiran manusia, ia mempunyai kekuatan menggerakkan, oleh karenanya meme bisa bersifat transformatif juga replikatif. Terdapat dua sistem repetisi dalam meme :

\section{a. Static repetition}

Repetisi statis merupakan pengulangan yang tidak berubah, sesuatu diulang dari generasi ke generasi berikut persis sama seperti sesuatu yang sebelumnya.

Static repetition: - to repeat

- to continue

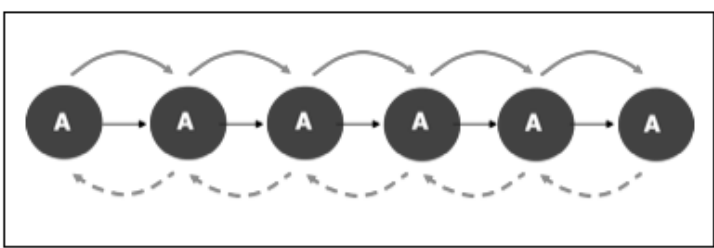

Gambar 3. Ilustrasi Stastic Repetition Sumber: Piliang. 2010

\section{b. Dynamic repetition}

Repetisi dinamis merupakan pengulangan yang menyertakan perubahan sebagai pemaknaan baru bagi sesuatu untuk menjadikan sesuatu itu lebih baik/berguna/tepat menurut kondisi yang diinginkan.

\section{Dynamic Repetition: - to change \\ - becoming}

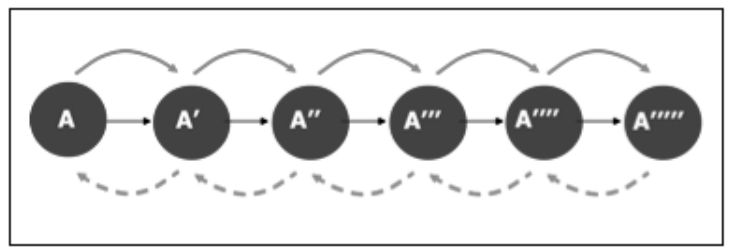

Gambar 4. Ilustrasi Dynamic Repetition Sumber: Piliang. 2010

Dari tinjauan teori tersebut maka dapat disimpulkan bahwa persepsi visual seseorang dapat timbul diakibatkan dari memori yang diakses kembali yang kemudian menimbulkan persepsi terhadap suatu karya visual. Dalam konteks LINE Sticker set "Alumni AADC Special stickers" ini peran memori menjadi unsur yang sangat krusial dimana memori menjadi konten utama daya tarik kepada calon pengguna sticker ini dan menghasilkan keuntungan. Kedekatan memori yang lekat secara visual menjadi unsur penjual. 


\section{ANALISIS}

Karakter Rangga diperankan oleh Nicholas Saputra. Rangga dikisahkan sebagai anak seorang dosen yang pernah tersandung masalah karena sering menulis dan mempublikasikan kebobrokan pemerintahan orde baru, hal tersebut mengakibatkan keluarga Rangga sering mendapat teror dari orang-orang tak dikenal, akibatnya Rangga hidup berdua dengan sang ayah karena ditinggalkan oleh ibu dan kakaknya. Rangga tumbuh sebagai pribadi yang dingin, individualistis namun cerdas, ia tak punya banyak teman, sahabatnya disekolah adalah seorang penjaga sekolah bernama bapak Wardiman. Kompleksitas kehidupan yang harus dihadapi Rangga pada usia muda menjadikan dia terlalu cepat menganggap asumsi sebagai kebenaran dan bersikukuh terhadap anggapan tersebut yang pada akhirnya menimbulkan konflik. Kecintaan Rangga terhadap karya sastra menjadi bagian penting dari kehidupannya, dibagian akhir film AADC (2002) ia pindah dan tinggal di kota New York, Amerika Serikat bersama ayahnya.

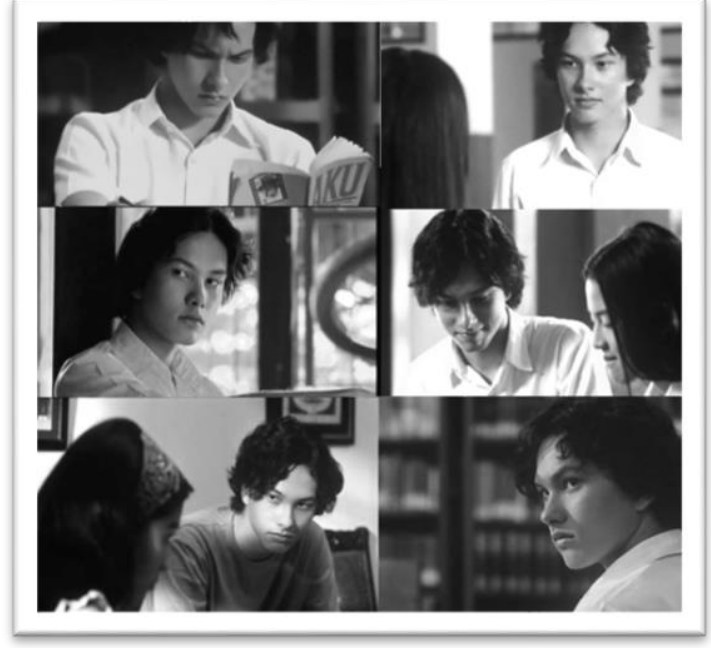

Gambar 5. Karakter rangga dalam Film Ada Apa Dengan Cinta (2002) Sumber: Miles Film. 2010
Tokoh Rangga merupakan tokoh utama dalam film AADC, dia menjadi penggerak cerita yang sangat dominan. Rangga merupakan tokoh protagonis, tetapi tidak semua sisi kehidupannya baik (sempurna). Gambaran dari sisi psikologis Rangga disampaikan secara kontekstual, dia adalah sosok pendiam dan penyendiri atau introvert, tidak suka basa-basi, kalem dan dingin, kebiasaannya selalu berada di ruang perpustakaan dan dibelakang sekolah sambil membaca buku sastra. Kemanapun Rangga pergi, dia selalu membawa buku berjudul "Aku" karya Sumandjaya. Tokoh Rangga di Film AADC (2002) mengalami perkembangan karena terjadi perubahan sikap setelah bertemu tokoh Cinta. Tokoh Rangga yang sensitif tetapi memiliki hati yang pemaaf dan bertanggung jawab, tercermin dari sikap Rangga yang selalu meminta maaf atas semua perlakuan Rangga terhadap Cinta.

Berlainan dengan karakter Rangga pada film AADC 2002, maka pada iklan LINE - AADC mini drama 2014 karakter Rangga menjadi sosok figur yang digambarkan sebagai orang dengan karir cemerlang di New York, nampak jauh lebih mapan dan lebih dewasa, meski masih digambarkan sebagai orang yang dingin dan cenderung menyendiri di tengah kesibukannya. Tampilan Rangga yang dulu digambarkan sebagai seseorang yang introvert dan cenderung tidak memiliki teman karena latar belakang psikologisnya, kini lebih digambarkan sangat mampu berinteraksi dengan rekan (klien) dalam pekerjaannya. 


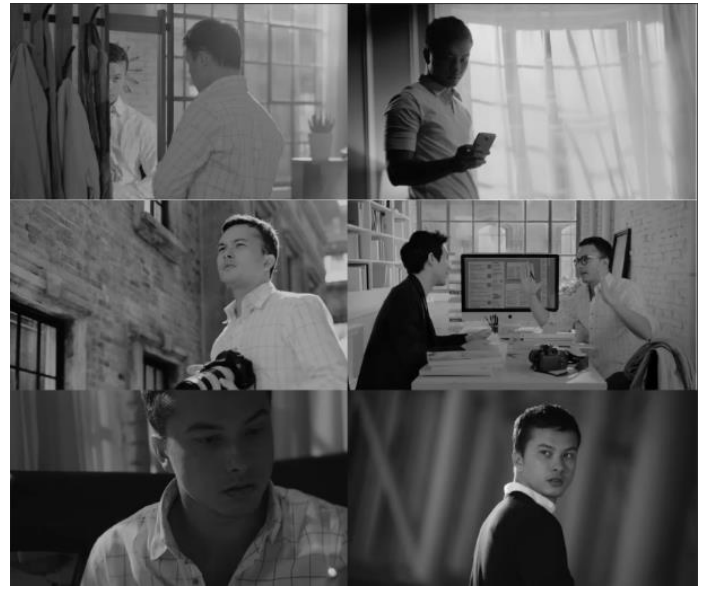

Gambar 6. iklan LINE - Ada Apa Dengan Cinta (AADC) 2014. Sumber: Youtube

Namun dalam iklan LINE - AADC Mini Drama 2014, tokoh Rangga juga ditampilkan seolah-olah dia tetap senang menyendiri nampak dari beberapa adegan saat dia duduk sendiri di dalam rumahnya, karakter Rangga yang sensitif tetapi memliki hati yang pemaaf dan bertanggung jawab pun tetap nampak pada Iklan LINE ini. Dimana saat Rangga meminta maaf lewat pesan LINE yang dia ketik karena merasa telah menganggu Cinta yang tak membalas pesan-pesannya sebelum dia kembali ke New York.

\begin{tabular}{|c|c|}
\hline $\begin{array}{l}\text { Karakter } \\
\text { Rangga }\end{array}$ & Analisa \\
\hline $\begin{array}{l}\text { Ada Apa } \\
\text { Dengan } \\
\text { Cinta } \\
(2002)\end{array}$ & $\begin{array}{l}\text { Denotasi : Seorang siswa SMA, duduk sendiri } \\
\text { di perpuskaan. membawa buku berjudul } \\
\text { "AKU" kemana pun dia pergi, jarang } \\
\text { tersenyum, terlihat selelu serius, tatapan } \\
\text { mata yang tajam, senang menyendiri tidak } \\
\text { memiliki teman dekat. Pergi kemana pun } \\
\text { mengunakan angkutan umum (bis kota), } \\
\text { Konotasi: Seorang anak SMA yang kurang } \\
\text { bergaul dan senang menyendiri. }\end{array}$ \\
\hline $\begin{array}{c}\text { Iklan } \\
\text { LINE } \\
\text { AADC } \\
2014\end{array}$ & $\begin{array}{l}\text { Denotasi : Seorang yang tinggal di New York } \\
\text { amerika serikat, berpakaian rapih dan trendi, } \\
\text { tinggal rumah dengan gaya brooklyn. Terlihat } \\
\text { sibuk dengan pekerjaan, bekerja } \\
\text { mengunakan kamera, duduk di bar bersama } \\
\text { rekan-rekan kerja. Diam sendiri di airport } \\
\text { sambil mendengarkan musik di earphone } \\
\text { Konotasi: Rangga yang lebih dewasa, sukses } \\
\text { dan modis. }\end{array}$ \\
\hline
\end{tabular}

Tabel 1. Analisa Semiotika Karakter Rangga pada AADC 2002 dan Iklan LINE AADC 2014
Tidak terlalu banyak perubahan yang tampak dari tokoh Rangga dalam iklan LINE - AADC Mini Drama 2014, walaupun banyak perubahan yang terjadi pada karakter Rangga. Image pendiam dan penyendiri atau introvert, tidak suka basa-basi kalem dan dingin, yang sudah melekat dibenak para audience tetap di pertahankan. Hal ini menunjukan asumsi audience pada film pendek ini bersumber pada memori mereka akan katakterisitik Rangga yang sudah terbentuk di film AADC 2002.

\begin{tabular}{|c|c|c|}
\hline No. & LINE Sticker & Analisa \\
\hline 1 & & $\begin{array}{l}\text { Denotasi : Ekspresi } \\
\text { Rangga yang datar sedikit } \\
\text { senyum dan tambahan } \\
\text { kata "Hai" (balon kata). } \\
\text { Konotasi: Sapaan atau } \\
\text { ajakan untuk berkenalan } \\
\text { (memulai pembicaraan) } \\
\text { dengan cara yang } \\
\text { cenderungagresif. }\end{array}$ \\
\hline 2 & & $\begin{array}{l}\text { Denotasi : Tatapan mata } \\
\text { yang tajam seakan sedang } \\
\text { marah dan penuh } \\
\text { kebencian ditambah } \\
\text { balon kata "Saya Sibuk". } \\
\text { Konotasi: Tidak Mau } \\
\text { diganggu (baca: marah). }\end{array}$ \\
\hline 3 & & $\begin{array}{l}\text { Denotasi : Ekspresi } \\
\text { pengakuan dengan kesan } \\
\text { menyepelekan. Ditambah } \\
\text { dengan balon kata } \\
\text { "lumayan" + ikon "nafas". } \\
\text { Konotasi: mengakui } \\
\text { kehebatan lawan bicara } \\
\text { tetapi merasa tidak lebih } \\
\text { hebat dari dirinya (baca: } \\
\text { keangkuhan). }\end{array}$ \\
\hline 4 & & $\begin{array}{l}\text { Denotasi : } \\
\text { tersenyum di tambah } \\
\text { dengan tatapan yang } \\
\text { tajam, ditambah dengan } \\
\text { teks "HeHe" (tawa ringan) } \\
\text { Konotasi: Tertawa yang } \\
\text { tidak terlalu tulus dan } \\
\text { cenderung basa-basi. }\end{array}$ \\
\hline 5 & & $\begin{array}{l}\text { Denotasi : tatapan tajam } \\
\text { dengan menundukan } \\
\text { kepala dan bibir yang } \\
\text { sedikit naik seakan-akan } \\
\text { sedang menantang } \\
\text { (mengajak berkelahi), } \\
\text { ditambah kata "So What?" } \\
\text { (Memang Kenapa?). }\end{array}$ \\
\hline
\end{tabular}




\begin{tabular}{|c|c|c|}
\hline & & $\begin{array}{l}\text { Konotasi: sifat bertindak } \\
\text { semaunya, cenderung } \\
\text { tidak mengikuti aturan. }\end{array}$ \\
\hline 6 & IV & $\begin{array}{l}\text { Denotasi : posisi dagu } \\
\text { yang naik, alis yang naik, } \\
\text { ditambah dengan bibir } \\
\text { yang seperti sedang } \\
\text { bersiul. } \\
\text { Konotasi: Jahil dan } \\
\text { seperti menyembunyikan } \\
\text { sesuatu }\end{array}$ \\
\hline
\end{tabular}

Tabel 2. Analisa Karakter rangga pada Sticker LINE "Alumni AADC Special stickers"

Dari analisa diatas dapat di simpulkan bahwa adanya ketidak sesuaian citra karakter Rangga dalam Film dan Iklan dengan Sticker LINE. Pada Film AADC 2002 dan Iklan LINE -AADC 2014, Rangga digambarkan sebagai orang yang introvert dan tidak senang basa-basi. Tidak pernah digambarkan menyapa seseorang atau mengajak seseorang berkenalan terlebih dengan ekspresi sepeti yang di visualisasikan dalam sticker ini. Walaupun dalam iklan LINE -AADC 2014, Rangga yang pertama kali mengirim pesan kepada Cinta, kata yang di gunakan adalah "cinta?" sebuah kata yang tidak seagresif "hai", maka kata "hai" dan ekspesi pada sticker nomer 1 tidak relevan dengan citra karakter Rangga, karena Rangga bukanlah orang yang akan menyapa atau mengajak berkenalan (memulai pembicaraan) dengan cara yang cenderung agresif.

Pada Film AADC 2002 terdapat scene dimana Cinta hendak mewawancarai Rangga sebagai pemenang lomba puisi, Cinta menghampiri Rangga yang tengah membaca buku di perpustakaan, saat diminta untuk wawancara Rangga mengatakan dengan datar dan dingin: "saya sedang sibuk", adegan itu sangat menjadi ikon dalam film AADC 2002. Sticker ini bertujuan me-recall memori audience pada adegan teresebut. Akan tetapi tatapan mata yang tajam seakan sedang marah dan penuh kebencian ditambah balon kata "Saya Sibuk" yang tampak pada sticker nomer 2 cenderung nampak tidak mau diganggu (baca: marah).

Pada Film AADC 2002 dan Iklan LINE AADC 2014), tidak pernah menggambarkan Rangga sebagai sosok yang angkuh atau menganggap rendah orang lain seperti yang di gambarkan pada sticker nomer 3, yaitu eksperesi mengakui namun menyepelekan, ditambah dengan balon kata "lumayan" dan ikon "nafas".

Sedangkan ekspresi tersenyum, tatapan mata yang tajam, ditambah dengan teks He-He (tertawa ringan) pada Sticker nomer 4, sangat tidak relevan dengan apa yang divisualisasikan pada Film dan iklan AADC, Rangga di gambarkan sebagai orang tidak senang basa-basi, tidak pernah digambarkan dalam kondisi gembira (tertawa).

Pada sticker nomer 5 dimana Rangga digambarkan dengan tatapan tajam dengan menundukan kepala dan bibir yang sedikit naik seakan-akan sedang menantang (mengajak berkelahi), ditambah kata "So What?" dianggap tidak mewakili citra karakter Rangga, walaupun Rangga pernah digambarkan berkelahi dalam salah satu adegan pada Film AADC 2002, dimana Rangga digambarkan di keroyok oleh Borne (teman Cinta) dan kawan-kawannya. Penyebab perkelahian tersebut lebih karena Borne merasa Rangga mendekati Cinta, dan adegan tersebut tetap tidak sesuai dengan apa yang di gambarkan pada sticker nomer 5, karena Rangga tampak cenderung 
terlihat seakan-akan yang memulai perkelahian dan tampak sangat arogan.

Karakter visual Rangga yang dicitrakan pada Film AADC (2002) dan iklan LINE AADC (2014) tampak relevan dimana karakter Rangga di gambarkan berkembang menjadi lebih dewasa dan menimbulkan opini dan persepsi baru tentang karakter Rangga yang hadir 12 tahun sebelumnya. Namun beberapa ciri karakter Rangga yang menjadi kunci dimana Rangga adalah orang yang serius, penyendiri dan misterius tetap di pandang sebagai ciri khas sosok Rangga yang tidak berubah, maka dari itu kharisma sosok Rangga yang ada di kepala audience sangatlah lekat dengan citra yang seperti itu. Hal tersebut sangatlah bertentangan dengan persepsi yang timbul dari visualisasi karakter Rangga yang muncul di Stiker LINE. Dimana Rangga digambarkan (sesuai analisa) sangat bertentangan dengan citra Rangga yang telah terbentuk dari film dan iklan AADC. Maka dari itu jika di kaitkan dengan teori Meme Dynamic Repetition. Dimana simbol yang di manifestasikan atas simbol-simbol sebelumnya haruslah mempertahankan kulitas simbol dimana antara satu dengan lainnya harus terdapat keterkaitan. Pada ilustrasi pertama penulis mencoba menggambarkan hubungan repetisi simbol antara ketiga karya AADC yang menampilkan karakter Rangga.

Seperti yang sudah di jelaskan sebelumnya, hubungan ke-tiga karya tersebut memiliki pola A-A'-B dimana karakter Rangga pada line sticker tidaklah sejalan dengan apa yang di citrakan sebelumnya. Padahal, jika mengaitkan dengan teori memori visual. karakter Rangga di tiap kemunculannya setelah Film AADC yang pertama pada tahun 2002 pasti akan membawa audience untuk me-recall ingatan mereka tentang image Rangga di film AADC (2002). dengan kata lain Film AADC (2002) merupakan "poros" simbol yang akan menjadi acuan dalam penerapan teori Meme Dynamic Repetition sehingga seberapa banyak apa pun simbol yang berkambang simbol-simbol tersebut akan merujuk simbol yang di awal atau yang di jadikan "poros" simbol.

Peran karakter Rangga dalam stiker line ini sangatlah krusial selain sebagai daya tarik pengguna LINE untuk mengunduh stiker tersebut, namun juga sebagai simbol komunikasi yang tidak dapat ucapkan (nonverbal) tentunya dengan memanfaatkan image yang telah terbentuk di benak audience yang tentunya akan menjadi sangat khas jika di manfaatkan. Namun, dalam stiker set ini image Rangga yang seperti pada film justru tidak tampak. Pada stiker aplikasi Line ini yang ditampakkan secara visual hanyalah, wajah artis Nicholas Saputra semata dengan tambahan balon kata atau ikon visual saja. Hal tersebut tentu saja sangat melemahkan fungsi dan kualitas komunikasi visual yang ada pada stikerstiker tersebut, mengingat pengguna aplikasi Line di Indonesia yang terbanyak di dunia dan film AADC yang mem-booming pada masanya.

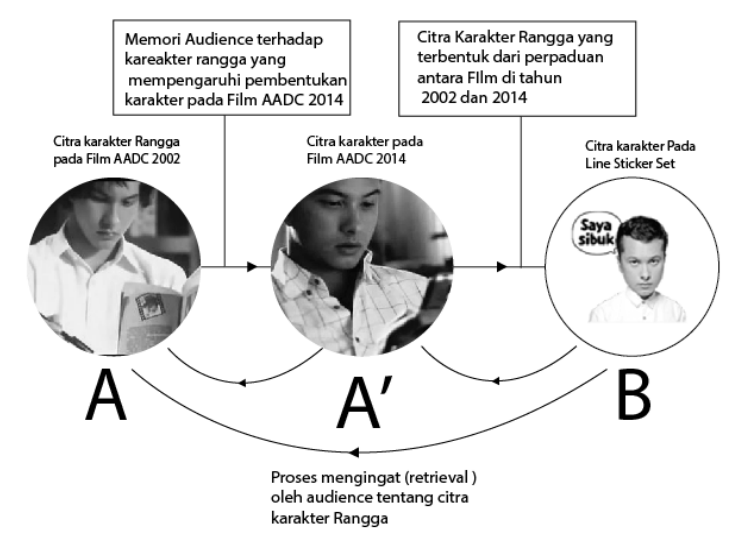

Ilustrasi 1. Dynamic repetition karakter Rangga 


\section{KESIMPULAN}

Penelitian ini membuktikan bahwa hubungan kulitas Karakter Rangga sebagai simbol yang ber-repetisi, tidaklah berjalan secara baik dimana karakter Rangga yang divisualisasikan secara tidak relevan dengan manifestasi karakter Rangga pada Film dan Iklan AADC sebelumnya. Hal tersebut dirasa perlu di perhatikan mengingat Stiker Line "alumni AADC" ini merupakan produk yang di perjual belikan oleh LINE dalam rangka mendukuang promosi fitur baru mereka yaitu Find Alumni. Walaupun daya tarik stiker set tersebut ada pada "equitas" film AADC sebagai salah satu film tersukses di Indonesia yang membuat penguna LINE tertarik untuk mengunduh. Dalam hal ini karakter Rangga yang menjadi poros simbol, sehingga image karakter yang di representasikan pada stiker LINE adalah karakter yang sejalan dengan image yang ada di kepala audience-nya. Sangat di sarankan meninjau ulang teori Meme Dynamic Repetition dalam setiap pengkaryaan LINE stiker yang memanfaat kan simbol-simbol populer yang dijadikan konten dalam perancangan LINE stiker, sehingga kualitas komunikasi visual pada setiap stiker yang di rancang dapat lebih sempurna. Seiring dengan perkembangan dunia ICT dan industri kreatif yang pesat, penelitian lebih dalam di ranah ini pun sangat di sarankan mengingat banyak penelitian yang belum membahas tentang Stiker, Emoticon dan Emoji di Indonesia.

\section{DAFTAR PUSTAKA}

[1] Derks, D., Fischer, A. H., \& Bos, A. E., 2008. The role of emotion in computer-mediated communication: A review. Computers in Human Behavior, 24, 766-785.

[2] McQuail, Denis. 1997. Teori Komunikasi Massa. Salemba Humanika, Jakarta.

[3] Olson, P. (2013). Teenagers say goodbye to Facebook and hello to messenger apps. Retrieved from http://www. theguardian.com/technology/2013/nov/10/teenagersmessenger-apps-facebook-exodus

[4] Piliang, Yasraf Amir. 2010. Post Realitas. Jalasutra, Yogyakarta. 1 maret 2010. Meme. S2 Desain ITB. Catatan kuliah.

[6] Riswandi. 2013. Psikologi Komunikasi. Graha Ilmu, Yogyakarta.

[7] www://line.naver.jp/en/ diakses pada tanggal 26 November 2014 pukul 12.45 WIB.

[8] https://id.berita.yahoo.com diakses pada 1 Desember pukul 13.05 WIB.

[9] http://inet.detik.com diakses pada 1 Desember pukul 14.00 WIB.

[10] Dir. Rudi Sujarwo. Ada Apa Dengan Cinta. 2002. Miles Film, Jakarta.

[11] Youtube. (2014 November 6) https://www.youtube.com/watch?v=56Sx2I1SRfA. 


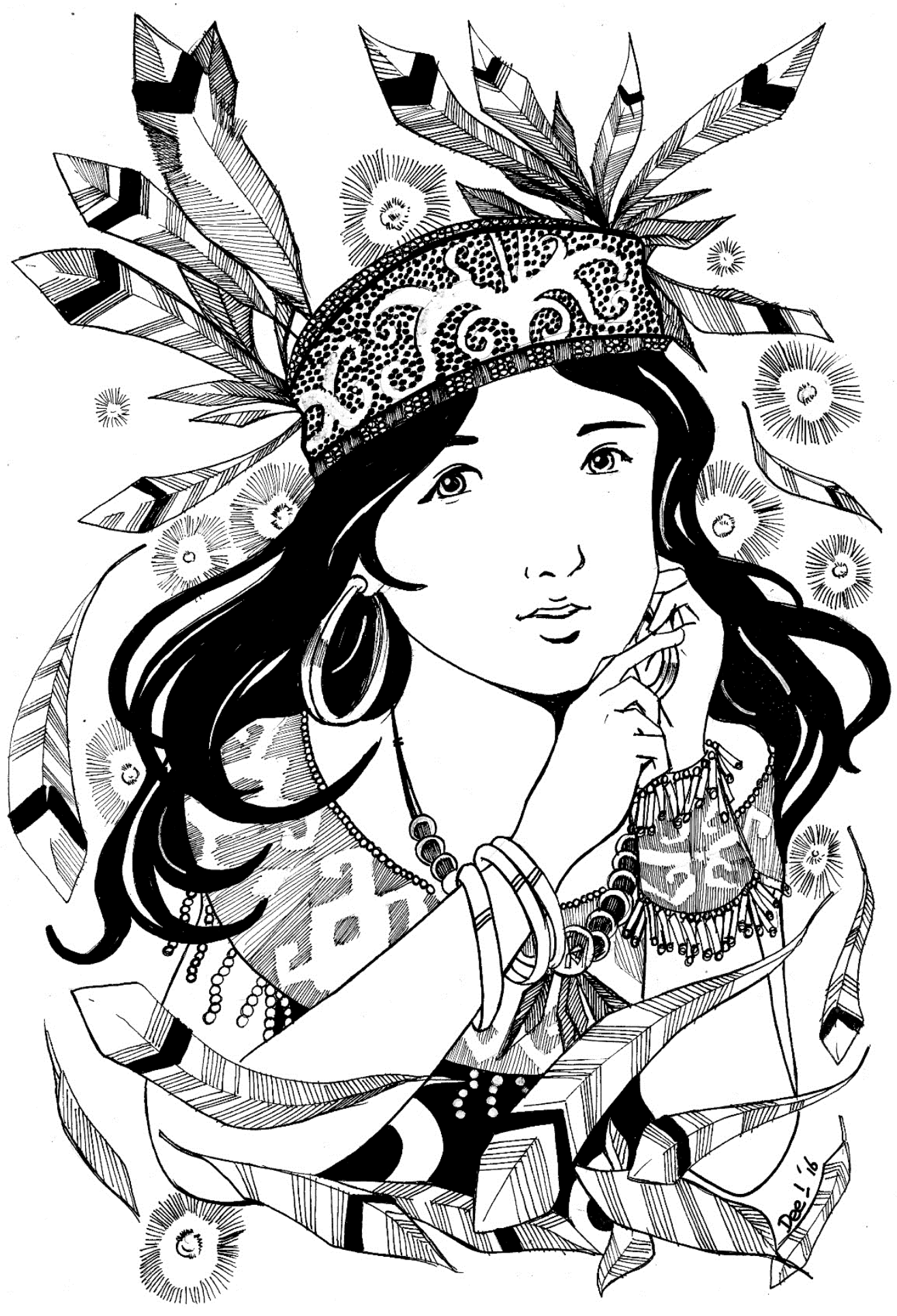

Borneo Beauty by Dimas Krisna Aditya, Mei 2016 